\title{
The Military and the Consolidation of Democracy: The Recent Turkish Experience
}

\author{
METIN HEPER AND AYLIN GÜNEY
}

$\mathrm{T}$

The significant differences among regions and even countries about the relations between governments and militaries make it impossible to develop an overarching theory of civil-military relations and the prospects for the consolidation of democracy. Prior to the transition to democracy, officers in Latin America functioned as political elites and exercised power in their own right; in contrast, officers in Eastern Europe were coopted by the communist parties and subjected to intense political indoctrination. Consequently, while in Latin America the consolidation of democracy required the demilitarization of politics, in Eastern Europe it required the depoliticization of the military. ${ }^{1}$

In Latin America, at the time of the transition to democracy the military retained too many privileges. ${ }^{2}$ Thus politicians in that continent wished to have greater say about the resources previously controlled by the military so that they could pursue client-oriented policies to garner votes, ${ }^{3}$ and they removed officers from state economic enterprises and allocated more funds to civilian ministries. ${ }^{4}$ In Eastern Europe, because the military had earlier come under the domination of communist parties, the depoliticization of the military by the political elite became critical. The best example here is Hungary, where Western democratic values have been quite successfully inculcated in the military. ${ }^{5}$

Turkey constitutes yet another case of civil-military relations that resemble the civil-military relations in Germany between the two World

METIN HEPER is the director of the Center of Turkish Politics and History, Bilkent University, Ankara, and a founding member of the Turkish Academy of Sciences. He is author of State Tradition in Turkey (1985), Historical Dictionary of Turkey (1994), and Ismet inönü: The Making of a Turkish Statesman (1998). Address correspondence to: Professor Metin Heper, Bilkent University, 06533 Bilkent, Ankara, Turkey; e-mail: heper@bilkent.edu.tr.

AYLIN GÜNEY is an instructor in the political science department at Bilkent University. She has contributed articles to such journals as Le Trimestr du Monde (Paris) and Armed Forces \& Society.

ARMED FORCES \& SOCIETY, Vol. 26, No. 4, Summer 2000, pp. 635-657. 
Wars and in France of the early 1960s. ${ }^{6}$ The consolidation of democracy in Turkey depended upon circumstances different from those in Latin America and Eastern Europe. As far as officers and, for that matter, the bulk of the Westernized elite in Turkey were concerned, an indispensable prerequisite for basing one's decisions on informed judgment had been secularism. ${ }^{7}$ This was because from the early part of the nineteenth century to the present, the elite in question equated Islam with irrationality; they thought that Islam had fallen out of phase with life and could not be adapted to modern circumstances. ${ }^{8}$ They perceived a close relationship between the demise of the Ottoman Empire and the persistent opposition of religion to the modernization efforts of the late eighteenth and the early part of the nineteenth centuries. Thus, these elite perceived secularism as the most important dimension of the republican ideology. In the republican period (1923 to the present), officers gradually became the most ardent guardians of secularism. The military's direct interventions in politics in Turkey in 1960-1961, 1971-1973, and 1980-1983 had the ultimate purpose of safeguarding the secular-democratic state in Turkey. ${ }^{9}$

At the same time, for officers, and for the rest of the Westernized elite in Turkey, modernization meant Westernization. They thus concluded that an important component of Westernization was democracy. However, they favored "rational democracy,"10 that is, taking democracy as an intelligent debate among the educated for the purpose of deciding upon the best policy option. " As a result, from the late nineteenth century onward, officers and the other Westernized elite increasingly perceived Turkey's salvation in introducing and maintaining a democratic as well as a secular state. It was thought, and the military agreed, that final authority rested with the civilian government. ${ }^{12}$

The antecedents of the military having a privileged position in Turkish polity hark back to the end of the thirteenth century when the military played a key role in the establishment of the Ottoman Empire. The Ottoman State was born as a ghazi (warrior) state on the borderland of two rival religions and civilizations. ${ }^{13}$ In the early centuries of the Ottoman Empire the military continued to play a primary role in state affairs. For this reason, for a long time the Ottoman ruling institution was referred to as Askeri (the military). During the period of decline (from the second part of the sixteenth to the end of the eighteenth century), the Ottoman state was virtually ruled by an oligarchy of the military, the civil bureaucracy, and the religious institution. During the nineteenth century, the military emerged first as the object and then the subject of modernization. ${ }^{14}$

The founders of the Turkish Republic (Atatürk and İsmet Inönü), too, had military backgrounds. During the single-party years of 1923-1950, 
although the military was subordinated to the civilian government, it was nevertheless considered as the ultimate guarantee of the secular republic. On the other hand, with a secular modern education in the 1930s and 1940s, the military emerged as the champion of a democratic as well as secular state. Thus, in the late 1940s, young officers in particular began to have sympathies for the newly emergent Democratic Party that challenged the "authoritarian rule" of the Republican People's Party (Cumhuriyet Halk Partisi or CHP). During the 1950s, the military shared the role of being a guardian of the secular-democratic state with the CHP. From the 1960s onward, with the fragmentation and polarization of Turkish politics on the dimensions of leftright, secular-Islamic, and cultural versus ethnic nationalism, and with the shift of the CHP from the center to the periphery, the military remained as virtually the sole protector of the secular-democratic state in Turkey. ${ }^{15}$

The military's assumption of this role had a legal basis as well. According to Article 35 of the Internal Service Act of the Turkish Armed Forces (enacted in 1961), "the military is responsible for defending both the Turkish Fatherland and the Turkish Republic as defined by the Constitution." According to the 1982 Turkish Constitution, the Turkish Republic is, among other things, a secular republic. Article 85 of the Internal Service Regulations of the Turkish Armed Forces stipulates that the "Turkish Armed Forces shall defend the country against the internal as well as the external threats, if necessary by force." The military plays a role in government through the participation of the High Command in the National Security Council (Milli Güvenlik Kurulu or MGK). The MGK is made up of the president, prime minister, ministers of national defense, internal affairs and foreign affairs, chief of general staff, commanders of the army, navy, air force, and of the gendarmerie. It convenes under the chairmanship of the president. According to Article 118 of the 1982 Constitution, the MGK "shall submit to the Council of Ministers its recommendations against the internal and external security of the country." The same article stipulates that the Council of Ministers gives priority to the recommendations of the MGK concerning the measures that the MGK deems necessary for the preservation of "the existence and independence of the State, the integrity and the indivisibility of the country, and the peace and security of the country."

It was in such a setting that on 28 June 1996, the religiously oriented Refah (Welfare) Party became the senior member of a coalition government (Refahyol) formed by Refah led by Necmettin Erbakan and the True Path Party led by Tansu Çiller. Refah's venerable leader Necmettin Erbakan became Prime Minister. ${ }^{16}$ This development caused consternation among the officers and the rest of the Westernized elite in Turkey, who became anxiety-ridden about the secular-democratic state in that country. 
As noted, the very target of the early republican reformers was the hold of religion on the society and the polity. ${ }^{17}$ Islam was to resemble the Protestant tradition that placed emphasis on the absolute privacy of individual conscience. After the death of Atatïrk, founder of Turkey, in 1938, apart from the return of Muslim chaplains to the army and the introduction of elective courses on Islam in the state grade schools, not much has changed. ${ }^{18}$ In the multiparty period (from 1946 to the present), the state continued to monitor Islam closely. As it has been aptly put, "Turkey has always allowed Islam to use what means it can to spread itself provided that the Islamic institution is not recreated outside and apart from the state." 19 Such limited religious openings in the 1950s as the reintroduction of the call to prayer in Arabic and somewhat expanded religious instruction in the grade schools were not the product of profound soul-searching or of a spiritual crisis. They were the consequences of chiefly utilitarian and political considerations-the quest for a secure foundation of common morality, the need for a united front against communism, and, above all, the never-ending competition for electoral votes.

It is not surprising, therefore, that Turkish Islam has been described as "simple" and not "fanatical." 20 In 1957, when asked if renewed interest in religious duties involved a possible return to the Shari'a, the majority of urban and educated Turks smilingly replied that there was no question of such a "retrogression" implied in their actions. Villagers were of like mind. ${ }^{21}$ In 1986, only seven percent of the people thought that the country should be ruled in accordance with Shari'a laws. ${ }^{22}$ In a nationwide survey carried out in February 1999, a mere 0.6 percent of the respondents considered themselves "very much religiously oriented." In the same survey, only 8.0 percent disagreed with the statement, "If a woman believes in God and the Prophet Mohammed she would still be considered a Muslim even if she does not cover her hair" and only 1.0 percent thought that adultery should be punished according to Islam..$^{23}$

Therefore, what Dankwart A. Rustow had said of the National Salvation Party (Milli Selamet Partisi or MSP) of the 1970s, Refah's predecessor, was not surprising: "[the MSP] would feel profoundly repelled by any regime of [Iran's] Shiite ayatollahs." ${ }^{24}$ The MSP could garner 11.9 and 8.6 percent of the votes in the 1973 and 1977 national elections, respectively. It is true that in the 1995 national elections, Refah could obtain 21.3 percent of the votes. This could, however, be explained primarily by secular rather than religious factors. Prior to the elections, the moderate left and the moderate right were divided among themselves; the secular parties had an unfavorable record that included cases of corruption and constant squabbling among their leaders, while, to many people, Refah was a symbol of integrity and morality. Also the party had a very effective grassroots organization. ${ }^{25}$ 
Furthermore, Refah functioned as a social welfare agency. It secured appointments for people in hospitals and other public agencies, and through the municipalities it controlled, the party distributed coal, clothing, soup, and food to the needy ${ }^{26}$ Then, in the 18 April 1999 national elections, at a time when the secular establishment in Turkey talked of a serious threat from political Islam, Refah's successor Fazilet (Virtue) Party obtained only 15.2 percent of the votes and came third after the Democratic Left Party and the Nationalist Action Party.

All the same, when Refah became the senior partner of the coalition government in 1996, as noted, many in the secular establishment perceived Refah as a serious menace to Turkey's secular regime. They argued that the party's endorsement of the secular-democratic order in Turkey was no more than taqiyya, ${ }^{27}$ or dissimulating one's faith on grounds of expediency. ${ }^{28}$ They pointed out that Refah leaders themselves had openly disclosed that their party was not only an alternative to other political parties but also to the secular-democratic order in Turkey. ${ }^{29}$

Some students of Islam and politics in Turkey had a more generous view of Refah. The latter thought that the party's mainstream leadership, if not a few militants among the rank-and-file, was oriented toward the electoral process. ${ }^{30}$ They argued that behind its radical rhetoric, Refah often showed pragmatism and flexibility. ${ }^{31}$ It was pointed out that this was the result of a strategic decision the party took in its Fourth Grand Congress (October 1993) to open up the party to new groups in the electorate. ${ }^{32}$

Outside observers tended to side with the pessimists. ${ }^{33}$ Officers in Turkey were among those who had serious concern about Refahyol. Consequently, following the formation of Refahyol, there was talk among the pessimists of either the eventual success of political Islam or another overt military intervention in Turkey. Neither of the two scenarios materialized, and a secularly oriented coalition government replaced Refahyol.

Later we first take up the developments that the military perceived as a threat to Turkey's secular-democratic order. Next, we delineate how the military tried to deal with that "threat" while trying to remain within the formal legal rules and how in the end the crisis was defused. ${ }^{34}$ Finally, we discuss the Refahyol crisis from a comparative perspective and also offer some thoughts about the likelihood of the consolidation of democracy in Turkey in the near future.

\section{The Military, Secularism, and Refah}

From the very beginning, the military did not look with sympathy on Refah's participation in government. Having strong suspicions about Refah's 
secular as well as democratic credentials, officers were worried lest Refah had in mind "one man, one vote, one time." However, following Refahyol's obtaining a vote of confidence ( 7 July 1996), in contrast to what the Algerian military had done under similar circumstances, officers in Turkey adopted a strategy of wait-and-see. In Algeria, the military had displayed opposition, there had been an absence of a national consensus about the rights of the opposition, and the military had been prone to act totally outside the law. Thus, in 1992 the military in Algeria prevented the Islamic Salvation Front (FIS) from coming to power and, furthermore, they eliminated the Front's moderate political leadership. ${ }^{35}$

In Turkey, during the wait-and-see period in question (July-December 1996), a report submitted to the National Security Council (MGK) by the National Intelligence Agency (January 1997) indicated that a number of religious orders and associations were trying to create "alternative state structures." 36 Another report prepared by the General Directorate of Security pointed out that more than 300 Islamic organizations have been "trying to bring back to Turkey an order based on Shari'a." ${ }^{37}$ A second report by the same Directorate noted that such Islamist groups as Hizbullah (the Party of God) and Islami Büyük Akincilar Cephesi (Great Raiders' Front of Islam) were particularly dangerous. ${ }^{38}$ As would be expected, these reports further alarmed the military.

The military also became disturbed by the accumulation of large amounts of funds in the hands of some Islamic holding companies. According to the military intelligence, the funds collected from Turkish workers abroad by the radical Turkish Islamic organizations based in other countries were channeled to Islamic holding companies in Turkey. The military came to the conclusion that the funds in question were being used to support the cause of political Islam. ${ }^{39}$

The military was also concerned about the number of students graduating from the Prayer Leader and Preacher Schools (Imam-Hatip Okullari) (sixth through eleventh grades). According to the military's intelligence, even though the annual need for religious functionaries in the late 1990s was around 3000 , every year more than 50,000 students graduated from these schools. In addition, in the 1996-1997 academic year, 1,685,000 students were attending the illegally offered Koran courses, and this number has been doubling every year. ${ }^{40}$ Although the Prayer Leader and Preacher Schools had been operating under the supervision of the Ministry of Education, there were claims that the values and attitudes inculcated in students at these schools could easily turn them into proponents of political Islam. The military felt uneasy about Refah's further packing the public bureaucracy with its co-ideologists. ${ }^{41}$ 
A more immediate concern of the military had to do with certain projects Refah had in mind. According to one such project, (1) only those who knew Arabic were to be admitted to the Foreign Ministry, (2) diplomats at foreign posts were to practice their religion; chapels (mescit) were to be set up at Turkish embassies, and (3) every Turkish representative abroad was to act as a missionary for Islam. Refah also wanted the Chief of the General Staff to report to the Minister of Defense rather than to the Prime Minister.

Certain statements made by some militant members of Refah also alarmed the military. There was talk among the members of the secular establishment of closing the middle school sections (grades six to eight) of Prayer Leader and Preacher Schools, in effect making eight-year secular education (five years at the grade school and three years at the middle school) compulsory. In reaction to this idea, one Refah deputy from the city of \$anli Urfa, İbrahim Halil Çelik, said: "If you close these schools there would be bloodshed. It would be worse than Algeria. In such an eventuality I will be rejoiced to see bloodshed!... The army could not deal with even 3,500strong PKK [the Kurdish Workers' Party]. How will it cope with six million Islamists?"42 Earlier, another Refah deputy from Ankara, Hasan Hüseyin Ceylan, had stated that if Refah controlled the military academies, Turkey would be a much nicer place to live. He claimed that guns and tanks could not destroy Refah, adding that Turkey met its tragic end when it began to be ruled by a parliament. According to this deputy, the country was reborn when religiously oriented parties were formed, Refah being the last such party. ${ }^{43}$ Still earlier, Refah parliamentarian Sevki Yilmaz had said that when he was mayor of the city of Rize, on national days he did not attend the ceremonies held in front of the statues of Atatürk. In his opinion "visiting a blind and deaf rock was a sign of one's being a retarded person." 44

The military was also greatly upset by the so-called Jerusalem Night organized on 5 February 1997 by the Refah-controlled Sincan Municipality on the outskirts of Ankara. In a play staged in a makeshift tent, the protagonists booed Arafat, made statements along the lines used by the militant Hizbullah, and called for the return of Shari'a. This seems to have been the last straw. Four days later, tanks roamed the streets of Sincan. Everybody received the message; however, unwilling to make an overt intervention in politics, the military insisted that it was part of a preplanned military exercise.

After becoming the senior partner in Refahyol, Refah had given some signs of developing into a pro-system party with respect to the issue of secularism. For instance, it had scrapped its Islamic economic program of the Just Order (Adil Düzen), which was, among other things, against such an interest. The party had also abandoned its rhetoric against the West in 
general and Israel in particular, and had even ratified a defense agreement with Israel. ${ }^{45}$ Perhaps to make up for these "concessions" and appease its not too large but militant activists, Erbakan condoned certain acts and statements by the latter. The military perceived Erbakan's soft stance on this matter as evidence of his thinking along the same lines as well. After all, before Refahyol was formed, Erbakan himself was guilty of similar statements, although in each case he had later pointed out that he was misunderstood. On one such occasion, he had even declared that Islamists "will come to power either through normal channels or by shedding blood." 46

The military became doubly alarmed when, shortly after becoming Prime Minister, Erbakan visited a number of militantly Islamic states, including Iran and Libya. While in Iran, Erbakan openly expressed doubt about the soundness of the earlier unfavorable briefing given to him by the Turkish National Intelligence Agency (Milli İstihbarat Teskilati or MiT) about Iran. In Libya, when Muammar Qadhafi had publicly accused past Turkish governments for having acted in the interests of the U.S. and Israel and called for the establishment of an independent Kurdish state in southeastern Turkey, Erbakan remained silent. In the same speech, Qadhafi had talked of a Supreme Council of Islamic Commanders under his command, and had disclosed Erbakan's being a member of that Council; Erbakan did not deny it.

Erbakan's inviting the leaders of religious orders, including the militant ones, to a dinner party at his prime ministerial residence and religious leaders attending the dinner in their religious garb (11 January 1997), was the last milestone in the unfolding of the recent political crisis in Turkey. For one thing, the prime minister had overlooked the violation of one of the Republic's most important Westernizing legislation-the Dress Codewhich forbade religious personages to put on their religious clothing in public-let alone, of course, in the official residence of the prime minister. Even more significantly, following the dinner, one of the religious leaders had openly said that they had helped Refah to garner votes in the elections. ${ }^{47}$

\section{The Military, Democracy, and Refah}

The military in Turkey had always sought to find the appropriate formula to enhance democracy in that country. ${ }^{48}$ Thus, the commanders expressed their concern about political Islam openly for the first time at a meeting of the National Security Council (MGK) (17 August 1996), noting that the activities of militant Islamists constituted a major threat for Turkey. They proposed that the MGK should look into this matter at its next meeting. ${ }^{49}$ President Süleyman Demirel, who was chairing this meeting and 
who was anxious to prevent a showdown between the military and the civilian government, remained noncommittal; he merely pointed out that the MGK "could, of course, take up the matter." 50

Following the meeting, the president wrote letters to Refahyol leaders, warning them to act prudently on the issue of political Islam. At the same time, the president asked the commanders to remain in their barracks. Refahyol leaders did not pay attention to the president's warning. On 20 December 1996, a high-ranking general offered the view that nobody should expect a solution to the political problems from the military; rather, the solution should come from the civil society and the parliament. ${ }^{51}$ To back up this view, on 24 December 1996, Chief of the General Staff (CGS) İsmail Hakki Karadayi pointed out that both secularism, "which is the very essence of intellectual progress, liberty of conscience, and democracy," and liberal democracy, "which is the lifestyle of free, civilized, and modern individuals," are the fundamental characteristics of the Turkish Republic. ${ }^{52}$ The government gave short shrift to these statements, too.

At the 26 December 1996 meeting of the MGK, the commanders noted that since August of 1996, the Islamic threat had become greater by the day and reiterated their request that this matter be placed on the agenda of the MGK. The president was again noncommittal, indicating that he was going to look into the matter. The council's post-meeting press bulletin made it clear that at this stage too the council had left it to the government to adopt the necessary measures.

At the same time, the commanders set up the so-called West Study Group (Bati Calişma Grubu) (BÇG) in the General Staff headquarters. The $B C ̧ G$ was to monitor the activities threatening the secular republic and plan appropriate measures lest they become necessary. Among other things, the BÇG was to explore which groups might lend support to the military and which groups to the militant Islamists if an armed confrontation took place between them..$^{53}$

Demirel continued his efforts to defuse the crisis by keeping close contact with CGS Karadayi and sending new warning signals to Erbakan and Çiller. On 18 January 1997, in a briefing they gave to him, the commanders told the president that political Islam had become the number one threat and that the high command had no choice but to "actively concern itself with that threat." 54

At the next critical meeting of the MGK (27 January 1997), commanders complained that the activities of the militant Islamists were still not on the agenda of the MGK. The president replied by saying that he continued to warn the government about the Islamic threat, adding that nobody could substitute another regime for Turkey's secular-democratic republic. The 
commanders' response was that they were well aware of the president's earnest endeavors concerning this matter, but Prime Minister Erbakan and Deputy Prime Minister Çiller were refraining from taking the necessary measures; worse still, they were acting against the laws enacted to safeguard secularism. ${ }^{55}$ They drew attention to the prime minister's notorious invitation of the leaders of the religious orders to his official residence and to the fact that the deputy prime minister had recently said, "Politics is at the disposal of religion." 56 Commanders let it be known that if the MGK did not take up the matter it would be held responsible by the future generations. ${ }^{57}$

The president came to the conclusion that it would no longer be appropriate to prevent the council from discussing the issue at length. At the same time he wanted to give the impression that the discussion of the issue by the military did not mean that the military was taking things into its own hands. He argued that the commanders participated at the MGK meetings not as spokespersons for the armed forces but as the higher functionaries of the state who had expertise on security issues. ${ }^{58}$ Only after making this point did the president point out that the issue of political Islam was going to be on the agenda of MGK's next meeting on 28 February 1997.

The president spent the following four weeks trying to prevent a headon clash between the commanders and Refahyol. In a letter to Erbakan, the president wrote: "Article 2 of the Constitution stipulates that Turkish Republic is a democratic, secular, and social state based on rule of law....Threats the anti-secularist activities pose for the secular Republican State give rise to serious concern both in the society and in the state institutions. I would like to bring to your attention the need to implement intact those laws enacted to safeguard secularism...and prevent the fundamentalist views from penetrating into schools, local governments, universities, the judiciary, and the military." 59 On the religious Lesser Festival (id al-fitr ${ }^{60}$ (8 February 1997), in a message to the nation, the president's tone became harsher: "The exploitation of the people's religious feelings for political purposes constitutes a felony." ${ }^{\prime 61}$ He invited the public prosecutors to be vigilant on this matter, and asked civil societal groups to shed their indifference and play a more active role. Both Erbakan and Çiller still could not figure out the gravity of the situation. Çiller even declared that in the next elections her party could form an alliance with Refah. ${ }^{62}$

Demirel talked with Erbakan for the last time on February 21st, and reportedly "told him everything that could be said." He then advised Karadayi that it was necessary to have patience and stay "within the Constitution" and that "if one's patience snaps Turkey would face great difficulties in the days to come." At the time, Demirel told those close to him that he was trying to "put out the fire." 63 
At the 28 February 1997 meeting of the MGK, the commanders pointed out that if those who govern the country overlooked the threat the seculardemocratic republic faced and, to add insult to the injury, they themselves used religion for political ends, the republic would tatter at its very foundations. The commanders urged the members of the council to recommend to the government the necessary measures, adding that otherwise a critical threshold would be crossed, the implication being that then the military would be obliged to deal with the threat unilaterally. Deputy Prime Minister Çiller attempted to defend Refahyol by saying that religion could not be used for political purposes because she and her colleagues in her party-DYPstood guard for secularism. The commanders retorted by pointing out that they did so only in words and but not in deeds and gave some examples. As compared to Çiller, Erbakan was more soft-spoken. He did not challenge the commanders; he only requested that the council's recommendations should be expressed in general terms, adding that otherwise he would have problems in explaining them to his rank and file. Demirel, too, tried to make the recommendations more palatable to Refah so that Erbakan would sign the final document and the matter would not lead to a further escalation of the already tense political situation. The meeting ended by the MGK making eighteen recommendations to the government. Among those, the MGK wanted to see pupils attending a secular school for eight years before studying at the Prayer Leader and Preacher Schools.

The government dragged its feet on the MGK's recommendations. At the same time, to prevent the military from making a drastic move, Erbakan kept on saying that his party had harmonious relations with the military. The commanders tersely pointed out that that they "could not be in good terms with those who acted against the Atatürkist principles."

Still, the commanders did not press the issue in the next scheduled (March 1997) meeting of the council, with the hope that the government would soon start moving and they would not have to take unilateral action. At the April 1997 meeting of the council, the commanders once more brought the issue to the table. At the meeting, the necessity of monitoring the short, middle, and long-term planning, programming, coordinating, and budgeting concerning the measures to be adopted was acknowledged.

The commanders were reluctant to take unilateral action, but they were intent on not letting the matter be put on the back burner. On April 29th, the General Staff gave a briefing to the members of the media about the threat of political Islam. Meanwhile, in March and April, every night, starting at 9.00 p.m. sharp, many people began to protest Refahyol by turning off and on their lights at home for ten minutes. The people had started to display their support for the military. According to a nationwide survey conducted in 
October 1990, compared to other institutions in Turkey, the people had highest trust in the military (91.7\%). The same study had shown that only $49.7 \%$ of the respondents had trust in the political system. ${ }^{65}$ At the time, through a number of public statements they made, the peak organizations of interest group associations representing both business and labor also expressed their deep dissatisfaction with Refahyol.

The government still did not act. In order to put more pressure on Refahyol, on May 26th the commanders held an extraordinary meeting of the Supreme Military Council and dismissed a number of commissioned and noncommissioned officers on the grounds that they had sympathies for political Islam. At this point, Demirel told journalists that he had requested to CGS Karadayi that the military should refrain from making public statements. The president also pointed to "the need for an early election." 66 On June 10th, the general staff gave still another set of briefings first to the judiciary and the academia, then to the media, and finally to the business groups in order to mobilize the public in the hope that Refahyol would respond.

As the pressure on Refahyol increased, Çiller perceived this as her opportunity to take over the prime ministry from Erbakan. She first approached CGS Karadayi and asked him to support a minority government led by her. Karadayi told her that this was the exclusive business of the president and the parliament. ${ }^{67}$ Çiller then told Erbakan that the pressure from the military was unbearable and, therefore, Erbakan and she should change posts. Erbakan who apparently could not figure out whether the military would or would not take power into its own hands, agreed. On June 18th, Erbakan submitted his resignation to the president, both Çiller and he having in mind a game of musical chairs between them.

The president, however, surprised them by appointing Mesut Yilmaz, leader of the Motherland Party, as prime minister, despite the fact that Çiller and Erbakan together commanded a majority in parliament at the time. Soon, however, that majority melted down, and a new coalition comprising the Motherland Party, the Democratic Left Party, and the Democratic Turkey Party, supported from outside by the (new) Republican People's Party, received a vote of confidence. This was a coalition of secularly oriented parties. The commanders stated that they would continue to monitor the developments in the problem of political Islam, but that "now there was no need for them to be actively involved concerning the efforts to tackle that problem." When, however, at one point new Prime Minister Yilmaz asserted that now the government and not the military was responsible for dealing with the problem of political Islam, ${ }^{68}$ the military retorted that they had a constitutional duty to act as a watchdog concerning this critical matter. $^{69}$ 
On 16 January 1998, the Constitutional Court dissolved Refah, on the grounds that it had attempted to establish a state based on Islam. The court used as evidence some of the statements by militant Refahis noted above. Erbakan and four other Refahis, including İbrahim Halil Çelik, Hasan Hüseyin Ceylan, and \$evki Yilmaz, were banned from active politics for five years.

Refah was succeeded by the Fazilet (Virtue) Party, which is led by a moderate leader-Recai Kutan. With Fazilet, secularism began to be defined as religion not interfering in the affairs of the state and the state leaving religion alone. Women, including those who did not cover their hair and openly consumed alcoholic drinks, took their places not only in the municipalities the party controlled but also in the parliament. ${ }^{70}$ Perhaps most significantly, party members began to ask the crucial question of "where did we go wrong?" 71

Still, in the 18 April 1999 elections, Fazilet came fourth, in all probability due to the Refahyol debacle. The new government that has been formed by three secularly oriented parties (the Democratic Left Party, the Nationalist Action Party, and the Motherland Party), with Bülent Ecevit as Prime Minister, has so far displayed an effective and prudent governance and, not unexpectedly, has had cordial relations with the military. In December 1999, Turkey was designated as a candidate for full membership in the European Union. The military gladly received this development, although it would require it to have a definitely subordinate role to civilian governments.

\section{The Turkish Case in Perspective}

The recent Refahyol-military confrontation over political Islam in Turkey has shown that although civilian supremacy over the military has not yet been fully established, there is little reason to expect a direct military intervention in that country. Officers are not enthusiastic even for indirect intervention. When officers feel some kind of intervention is absolutely necessary, they make that intervention by mobilizing the democratic forces and by trying to remain within the legal framework. Despite the fact that in 1996-1997 commanders perceived political Islam as a serious threat to the secular-democratic state in Turkey they did not resort to direct action. Instead, they chose to pressure the government via a constitutionally sanctioned mechanism-the MGK - to act more prudently. They justified their limited intervention in politics by reference to the constitutional provisions and their internal code that saddled them with the responsibility of safeguarding the republic from internal as well as external threats. 
In the wake of the military's intervention in politics in 1980, Frank Tachau and one of the present authors had commented that "it should occasion little surprise...if the military retain (either overtly or covertly) some share of the guardianship of the state." 72 Recently the military in Turkey chose a moderating role-exercising influence and even effecting a change of government-without taking the helm of government into its hands. The military tried everything it could so that they would not feel obliged to escalate their moderating role to a guardianship role-taking power into their hands, clearing up "the mess," and then returning to their barracks.

It may be argued that during the Refahyol crisis the military, in fact, acted basically as a pressure group, that is, as a group that aims to promote the general interest as it itself interprets it, without trying to come to office. It was true that the military as a pressure group was more than primus inter pares. And, of course, if absolutely necessary, its exhortations could be backed up by effective "sanctions." Still, the commanders preferred to have support in the polity. They attempted to recruit to the "common cause" various civil societal groups-the secularly oriented media, interest group associations of the business and labor-such bureaucratic groups as the judiciary and the academia, and the people themselves. They found a receptive and, in fact, an enthusiastic audience. No doubt this was in part a consequence of their high prestige in the polity. Such "outside" support facilitated a basically "non-armed forces solution" to the crisis.

Particularly critical for arriving at such a solution was the significant role President Demirel had played. Demirel prevented the crisis from escalating to a point of no return. He assured the commanders that a "non-armed forces solution" was possible. On the other hand, he kept the anti-Refahyol sentiment under control so that no major confrontation took place between the secularists and Islamists. ${ }^{73}$ As a consequence, secularists did not send signals to the military that they should intervene, as some secularists had done on the eve of the 1971 military intervention. ${ }^{74}$

Another contributing factor for a "non-armed forces solution" to the crisis was the new ability of the majority of the secularly oriented political parties to set aside their differences and cooperate when the country faced a serious threat to the secular and democratic state. It should also be noted that when Çiller chose not to join the bandwagon, because of her anger at having been "ignominiously removed from power," some of her close colleagues deserted her.

Another important development that would render this solution even more likely in the future is that, from the National Order Party to Fazilet, the religiously oriented parties in Turkey gradually freed themselves from the 
clutches of an Islamic ideology in order to appeal to larger groups of the electorate. The closure of these parties by either the constitutional court or in the wake of military intervention on the grounds that they promoted political Islam, provided a further momentum to this development. Consequently, Refah increasingly took on the trappings of a pro-system party. It came to power through democratic means. It used its Islamist themes basically to explain what was fundamentally wrong with the country, describing to the electorate fundamental mistakes the previous governments had made. Once in power, Refah shed many of its earlier utopian, if not militant, Islamic views.

The change had, in fact, started when Refah's predecessor-the National Salvation Party (MSP)—was in power (1972-1980). During those years, as compared with the period of the National Order Party (1970-1972), the MSP's predecessor, there was a tendency to have relations with the then European Economic Organization and an inclination to engender reform in specific state institutions rather than sweeping changes in the constitution. ${ }^{75}$ When Refah replaced the MSP, secular and religious world views were not seen as incompatible. Refah defined secularism as the freedom to practice one's religion according to one's belief and without harassment. ${ }^{76}$ The Refahis referred to the members of secular parties as "incompetent politicians" and not as "false Muslims," as their predecessors had done. ${ }^{77}$ On a symbolic level, but not less significantly, women began to attend party congresses, though with their hair covered, and more men began to wear neckties. ${ }^{78}$

It is true that the Refah party in general garnered votes in Turkey's underdeveloped regions. ${ }^{79}$ And there had been ethnic support for the party in the eastern and southeastern provinces.$^{80}$ However, Refah had essentially been a party of forward vision, placing emphasis on modern science and technocracy, and not a party of protest and rejection. If this had not been the case, in all probability Refah's votes would have been considerably fewer because the "Turks have been looking forward, not back." 81

Since the mid-1990s, Refah has adopted the procedural rules of democracy-those designating the constitutional means of competing for and holding political office. ${ }^{82}$ The party has not considered coming to power by means other than elections. Following its removal from office, many in the party began to seek an answer to the question of where the party had gone wrong. As noted, Recai Kutan, the leader of the Virtue Party, successor party to Refah, has so far given the impression that he is a leader with more moderate views than Erbakan on the issue of secularism. It is probable that in the near future, a moderate and an innovative generation of Islamist politicians will take over from the less moderate and orthodox old guard and 
Fazilet will definitely turn into a pro-system party. In Turkey, neither political Islam nor military rule seems to be in the cards, and the indications are that in the near future occasional indirect military presence in the polity will be replaced by consolidated democracy.

For the latter transformation to take place the military will need to have greater faith in the capability as well as the prudence of civilian governments. When the military has such faith, not only will there be no reason for military intervention, but Turkey will also have a "maximalist" notion of democracy, that is, the full hegemony of democratic values in the polity in addition to the holding of competitive elections on a regular basis. The consolidation of a "maximalist" notion of democracy in Turkey may take some time, because of the officers' penchant for "rational democracy" and because, at least until recently, of nonprudent political leadership. ${ }^{83}$ We say "until recently" because, as noted, the government formed by the three secularly oriented parties following the 18 April 1999 elections has so far displayed an effective and prudent governance that Turkey had lacked for quite some time.

During and in the wake of the Refahyol crisis, the Turkish military's approach to politics resembled those of their counterparts in France and Germany of the earlier decades. In both France and Germany the military identified its destiny with that of the nation. ${ }^{84}$ For instance, in both 1958 France and 1996-1997 Turkey, officers believed that civilians were indifferent to the long-term interests of the community. As officers in both countries conceived of themselves as national political overseers, they thought that when the national interest was in peril, but only then, they should set things right. Neither former French nor present-day Turkish officers were avid power seekers; in fact, both sets of officers remained aloof from day-to-day politicking. Their preference was to stay on the sidelines and obey political rulers. If they thought they had to come into the picture, they preferred the role of arbiter to that of exercising a veto power, and the latter to actual intervention. When they were engaged in "extracurricular activities," they wished to return to silence as soon as possible. During the recent decades, due to the absence of strong and effective governments, the Turkish military has been in the limelight more often than it would have preferred.

In France and Germany of the earlier decades and historically and presently in Turkey, the military constituted an integral part of what they considered a non-politicized state. In all three countries, at times they intervened in politics as the state elite and not as the political elite. They were not in a political competition with the political elite. They considered themselves as nonpartisan arbiters, and not as rivals to the political elite. Most of the time they have been on the sidelines and not in the political swirl, 
not because they have been forced to act in that manner, but because they thought it was proper for them to act in that manner.

Given the above characteristics of the military-civilian relations in Turkey, the theories formulated with a view to the democratization in Latin American countries on the one hand and Eastern European countries on the other do not have an explanatory value in the Turkish case. As noted, the recent democratization in Latin America has been explained by the theory of the mode-of-transition to civilian politics. According to this theory, whether the military had obtained too many privileges or not at the time of transition to multiparty politics is important. The assumption here is that if the military had too many privileges, then its full extrication from politics would be difficult. In Brazil, the military, which was obliged to enter into a pact with civilians through a process of bargaining, nevertheless continued to occupy six of the 22 cabinet posts. They scuttled the agrarian reform and blocked for some time the granting of the right to strike to workers. ${ }^{85}$

In Turkey, the military dominated the polity during the 1980-1983 interregnum. Yet in 1983, the military had completely returned to its barracks. Its participation in state affairs was limited to its role in the MGK; they did not concern themselves with social and economic policies, as their counterparts in Brazil had done.

In Argentina, the National Defense Law of 1988 separated external defense, the domain of the military, from internal security, for which essentially police forces and border patrols were made responsible. The law also banned the military from planning scenarios for internal conflict and from using military intelligence for domestic purposes. The same law also denied the military a seat on the National Defense Council, enabling civilians to set defense priorities all by themselves ${ }^{86}$ Even in Brazil similar processes were in motion. For instance, defense expenditures were cut and pork barrel spending increased. ${ }^{87}$

In Turkey, despite the increased democratization of the regime, the military's prerogatives were kept almost intact. ${ }^{88}$ And the military continued to use the MGK to influence government policy in those matters that they considered critical for the internal and external security of the country.

Similarly, the theory of electoral logic developed with a view to the democratization experience of Eastern European countries does not have an explanatory value in the Turkish case. ${ }^{89}$ As noted, according to this theory, democratization took place as progressive encroachments on the interests of the military by political parties that competed among themselves to garner votes. Following the demise of the communist regimes in Eastern European countries, the officers in those countries lost their former prestige. They were perceived as the servants of foreign (Soviet) and ideological (communist) 
rather than national interests. In contrast to the Latin American experience, democratization in Eastern Europe started with weak military establishments. Under these circumstances, in such countries as Romania and Poland, where presidential systems were adopted, the civilian executives politicized the military in order to use it for their own purpose. In Romania, for instance, the president expected the military to back his personal rule instead of defending the constitutional order. This has placed Romanian democracy in peril; the military in that country was seen as enthusiastic to take power into its own hands in case of political disorder. In many other countries, among which Hungary is the best example, the military was inculcated with democratic values and, at the same time, developed into a professional corps. In the latter set of countries, where parliamentary systems of government were adopted, the military became subservient to civilian politicians and were not inclined to intervene in politics.

In Turkey, in the wake of a return to democracy, officers were not in a weak position. Consequently, they could not be politicized by the civilian elite and turned into an instrument at the latter's disposal. The Turkish military always subscribed to the republican principles of secularism and (cultural) nationalism, and were perceived by the bulk of the populace as defenders of the national interest. On the other hand, from the 1950s onward, particularly following Turkey's becoming a member of the NATO, the military progressively developed into a professional body. In addition to their being always aloof from day-to-day politics, this fact also contributed to their basic unwillingness to be continuously involved in the swirl of politics. In their view, their interventions in politics undermined their combat effectiveness and esprit de corps.

The theory of "the mode-of-transition" has an explanatory value in the "politicized state of Latin America," to use Douglas Chalmers' terminology. ${ }^{90}$ The theory of "the electoral logic" and the politicized military versus a professional military dichotomy has an explanatory value in Eastern Europe, where the military could either be completely politicized or turned into a nonpoliticized professional body. Both theories are inadequate to explain civil-military relations in such countries as present-day Turkey as well as France and Germany of the earlier decades where there were professional, though "staticized," militaries. In the latter category of countries, there has been a state distinct from society and above politics, ${ }^{91}$ and democracy was a regime granted from above and not a regime forged through multiple confrontations, bargaining, and the professionalization of the military by civilian politicians. ${ }^{92}$ In such settings, particularly in Turkey, "historical institutionalism" that pays attention to the factors that determine 
the political orientations of officers, would provide better clues concerning the consolidation of democracy.

\section{Notes}

1. Zolan Barany, "Democratic Consolidation and the Military: The East European Experience," Comparative Politics 30 (October 1997): 27.

2. Terry Lyn Karl, "Dilemmas of Democratization in Latin America," Comparative Politics 23 (October 1990): 1-21, and Frances Hagopian, "Democracy by Undemocratic Means? Elites, Political Pacts and Regime Transitions in Brazil," Comparative Political Studies 23 (July 1990): 147-70.

3. Wendy Hunter, "Politicians Against Soldiers: Contesting the Military in Post Authoritarian Brazil," Comparative Politics 27 (July 1995): 425-43, and idem, "Continuity and Change? Civil-Military Relations in Democratic Argentina, Chile and Peru," Political Science Quarterly 112 (Fall 1997): 453-75.

4. Hunter, "Politicians against Soldiers," 429-40.

5. Barany, "Democratic Consolidation and the Military," 36.

6. We return to this point later.

7. Niyazi Berkes, Development of Secularism in Turkey (Montreal: McGill University Press, 1964): Chap. 17.

8. Nur Yalman, "Islamic Reform and the Mystic Tradition in Eastern Turkey," Archives Européennes de Sociologie 10 (1969): 41-42.

9. See, inter alia, Frank Tachau and Metin Heper, "The State, Politics, and the Military in Turkey," Comparative Politics 16 (October 1983): 17-33.

10. Metin Heper, "Extremely 'Strong State' and Democracy: Turkey in Comparative and Historical Perspective," in Democracy and Modernity, ed. S. N. Eisenstadt (Leiden: E. J. Brill, 1992).

11. On "rational democracy," we draw upon Giovanni Sartori, The Theory of Democracy Revisited. Part One: The Contemporary Debate (Chatham, NJ: Chatham House Publishers, 1987): 51-55.

12. William Hale, Turkish Politics and the Military (London: Routledge, 1994): Chap. 12. During the recent years the High Command itself several times underlined this point. For one such instance, see Sabah (Istanbul Daily), January 28, 1997.

13. Halil İnalcik, "Ottoman Methods of Conquest," Studia Islamica 2 (1954): 104-29.

14. See, inter alia, Metin Heper, The State Tradition in Turkey (Walkington, UK: Eothen Press, 1985): Chap. 2.

15. See, inter alia, Frank Tachau and Metin Heper, "The State, Politics, and the Military in Turkey," Comparative Politics 16 (October 1983): 17-33.

16. Erbakan had also been the leader of two religiously oriented political parties that preceded Refah-the National Order Party and the National Salvation Party. 
17. For an elaboration, see Serif Mardin, "Ideology and Religion in the Turkish Revolution," International Journal of Middle East Studies 2 (1971): 197-211.

18. Bernard Lewis, "Islamic Revival in Turkey," International Affairs 28 (January 1952): $39-40$.

19. C. H. Dodd, Democracy and Development in Turkey (Walkington, UK: The Eothen Press, 1979): 76.

20 Geoffrey Lewis, "Islam in Politics-A Muslim World Symposium: Turkey," Muslim World 56 (October 1966): 237.

21. Howard A. Reed, "The Religious Life of Modern Turkish Muslims," in Islam and the West, ed. Richard N. Frye (The Hague: Mouton, 1957): 116.

22. Ilter Turan, "Religion and Political Culture in Turkey," in Islam in Modern Turkey, ed. Richard Tapper (London: I. B. Tauris, 1991): 55.

23. Milliyet (Istanbul Daily), April 9, 1999.

24. Dankwart A. Rustow, “Turkey's Travails," Foreign Affairs 58 (Fall 1979): 98-99.

25. See Sencer Ayata, "Patronage, Party, and State: The Politicization of Islam in Turkey," Middle East Journal 50 (Winter 1996): 52.

26. Rupen Cakir, Ne Seriat Ne Demokrasi: Refah Partisini Anlamak (Istanbul: Metis, 1994): 185.

27. Birol A. Yesilada, "The Refah Party Phenomenon in Turkey," in Comparative Political Parties and Party Elites: Essays in Honor of Samuel. J. Eldersveld, ed. idem (Ann Arbor: The University of Michigan Press, forthcoming).

28. For this definition of taqiyya, we draw upon Faruq Sherif, A Guide to the Contents of the Qur'an (Reading, UK: Garnet, 1995), 122. The principle of taqiyya that belongs to the Shiite doctrine is not a generally accepted tenet of Islam, although two instances of such actions are mentioned in the Qur'an: making friends with infidels (III. 27) and denying God (XVI. 28). Ibid.

29. Sabri Sayari, "Turkey's Islamic Challenge," Middle East Quarterly 36 (September 1996), 39.

30. Jenny B. White, "Pragmatists or Ideologues? Turkey's Welfare Party in Power," Current History 606 (January 1997): 29.

31. Ergun Özbudun, "How Far from Consolidation Democracy in Turkey," Journal of Democracy 7 (July 1996): 134.

32. Metin Heper, "Islam and Democracy in Turkey: Toward a Reconciliation?" Middle East Journal 51 (Winter 1997): 37.

33. For an elaboration, see Aylin Güney-Avci, "Politique intérieure et politique extérieure dans la Turquie d'aujourd'hui," Le Trimestre du Monde 27 (September 1996): 8081 .

34. Concerning the march of events in this period, we primarily draw upon three Istanbul dailies, which have nationwide circulation-Hürriyet, Milliyet, and Sabah. 
35. See Lahouari Addi, "Algeria's Army, Algeria's Agony?" Foreign Affairs 77 (July/ August 1998): 45-53, and Eldin Shanin, Political Ascent: Contemporary Islamic Movements in North Africa (Boulder: Westview Press, 1997): 161.

36. Milliyet, January $17,1997$.

37. Ibid.

38. Ibid.

39. Sabah, June 12, 1997.

40. These numbers were disclosed to the media on 11 June 1997 in a briefing given by the Office of Chief of the General Staff.

41. On this practice by Refah's predecessor-the National Salvation Party-see Metin Heper, "Recent Instability in Turkish Politics: End of a Monocentrist Polity?" International Journal of Turkish Studies I (Winter 1979-1980): 102-13.

42. Hürriyet (Istanbul daily), May 10, 1997.

43. Sabah, November 12, 1996.

44. Hürriyet, June 1, 1997.

45. Ziya Önis, "The Political Economy of Islamic Resurgence in Turkey: The Rise of the Welfare Party in Perspective," Third World Quarterly 18 (1997): 743-66.

46. Sabah, April 14, 1997.

47. For a further elaboration of the activities of the Islamists that caused alarm in the military, see Yeșilada, "Refah Phenomenon in Turkey," and Sayari, "Islamic Challenge in Turkey."

48. See, inter alia, Birol Ali Yesilada, "Problems of Political Development in the Third Turkish Republic," Polity 21 (Winter 1988): 355.

49. The MGK meets every month.

50. Turkey has a parliamentary system of government with a somewhat strong president. The president, not unlike his French counterpart, is "responsible for the smooth functioning of the state organs." He appoints the members of the Constitutional Court and the State Supervisory Council, the members of the Council of Higher education, one-fourth of the members of the Council of State, the Chief Public Prosecutor, and the members of the Supreme Council of Judges and Prosecutors. He also prepares the agenda of the MGK meetings.

51. Hürriyet, December 12, 1999.

52. Sabah, December 12, 1996.

53. Hürriyet, June 12, 1997.

54. Hürriyet, August 23, 1997.

55. Milliyet, August 14, 1997.

56. Hürriyet, October 24, 1996. 
57. Hürriyet, August 23, 1997.

58. Ibid.

59. Hürriyet, August 25, 1997.

60. The three-day festival right after the Ramadan.

61. Hürriyet, August 25, 1997.

62. Ibid.

63. Ibid.

64. Sabah, March 3, 1997.

65. Üstün Ergüder, Yilmaz Esmer, and Ersin Kalaycioğlu, Türk Toplumunun Dĕgerleri (Istanbul: Türk Sanayicileri ve İsadamlari Derneği, 1991): 22.

66. Hürriyet, August 31, 1997.

67. Hürriyet, June 27, 1997.

68. Hürriyet, March 18, 1998.

69. Hürriyet, March 21, 1998.

70. Kemali Saybaşili, "Giris," in Onbir Aylik Saltanat: Siyaset, Ekonomi ve Dis Politikada Refahyol Dönemi, ed. Gencer Özcan (Istanbul: Boyut, 1998), 40.

71. Hürriyet, September 3, 1999.

72. Tachau and Heper, "The State, Politics, and the Military in Turkey," 32.

73. The 1982 Constitution provided the president with rights more extensive than those normally provided in parliamentary regimes. Among other things, the Constitution stipulated that the president is responsible for the harmonious functioning of the state organs. Thus concerning political stability and harmony in the country, Demirel adopted an activist role. The majority of politicians and intelligentsia criticized him of overstepping his authority; they wanted him to act as no more than a symbolic head of state. See Metin Heper and Menderes Cinar, "Parliamentary Government with a Strong President: The Post-1989 Turkish Experience," Political Science Quarterly $1 / 1$ (Fall 1996): 483-503. Thus, in helping to resolve the recent crisis, Demirel had to draw upon the high esteem he held in the country.

74. Hale, Turkish Politics and the Military, 187.

75. Ali Yapar Saribay, Türkiye'de Modernlesme, Din ve Parti Politikasi: MSP Örnek Olayi (Istanbul: Alan, 1985), 103-104.

76. Serdar Sen, Refah Partinin Teori ve Pratiği: Adil Düzen ve Kapitalizm (Istanbul: Sarmal, 1995), 121-122.

77. Soner Yalçin, Milli Nizam'dan Fazilete: Hangi Erbakan? 6th ed. (Istanbul: Su, 1999), 202.

78. Nuray Mert, islam ve Demokrasi: Bir Kurt Masali (Istanbul: İz, 1998), 15.

79. Ayata, " Patronage, Party and State," 53. 
80. Ibid., 53.

81 . White, "Pragmatists or Ideologues?" 28.

82. Jeremy Salt, "Nationalism and the Rise of Muslim Sentiment in Turkey," Middle Eastern Studies 31 (January 1995): 13-25.

83. For an elaboration of politicians' lack of prudence-bordering on irresponsibilityin Turkey, see Metin Heper and Fuat Keyman, "Double-Faced State, Political Patronage and the Consolidation of Democracy in Turkey," Middle Eastern Studies 34 (1998): 259-277. On how this state of affairs led to Refahyol crisis in Turkey, see, inter alia, Ben Lombardi, "Turkey: The Return of the Reluctant Generals," Political Science Quarterly 1/2 (Summer 1997): 200.

84. Klaus-Jurgen Müller, "The Military, Politics and Society in France and Germany," in The Military in Politics and Society in France and Germany in the Twentieth Century, ed. idem (Oxford: Berg, Publishers, 1995), 10.

85. Hagopian, "Democracy by Undemocratic Means?" 155-156.

86. Hunter, "Continuity or Change? Civil-Military Relations in Democratic Argentina, Chile and Peru," 464.

87. Idem, "Politicians Against Soldiers: Contesting the Military in Post-Authoritarian Brazil," 440.

88. We say "almost," because, once (July 1987) the military's candidate for the post of Chief of General Staff was successfully challenged by the Prime Minister. See Metin Heper, "The Executive in the Third Turkish Republic, 1982-1989," Governance 3 (July 1990): 314.

89. On the East European experience, we draw upon Barany, passim

90. Douglas Chalmers, "The Politicized State in Latin America," in Authoritarianism and Corporatism in Latin America, ed. James M. Malloy (Pittsburgh: University of Pittsburgh Press, 1977). Paul E. Sigmund's suggestion that for Latin America, "a careful analysis of the bargaining relationship between the military and civilians will be the appropriate focus analysis" lends credence to the view advanced here. See his "Approaches to the Study of the Military in Latin America," Comparative Politics 26 (October 1993): 122.

91. For a comparative study of the state in Germany and Turkey, see Metin Heper, "The Strong State and the Consolidation of Democracy: Turkey and Germany Compared," Comparative Political Studies 25 (July 1992): 169-194.

92. For a further elaboration of this point through a comparison of Turkey, Southern Europe, and Latin America, see Metin Heper, "Transitions to Democracy Reconsidered: A Historical Perspective," in Comparative Political Dynamics: Global Research Perspectives, eds. Dankwart A. Rustow and Kenneth Erickson (New York: Harper Collins, 1991). 
Copyright of Armed Forces \& Society is the property of Transaction Publishers and its content may not be copied or emailed to multiple sites or posted to a listserv without the copyright holder's express written permission. However, users may print, download, or email articles for individual use. 